\title{
KINERJA GURU BAHASA INGGRIS BERSERTIFIKAT PENDIDIK DI KOTA YOGYAKARTA
}

\author{
Rahmi Munfangati ${ }^{1)}$, Pratomo Widodo ${ }^{2)}$ \\ Universitas Ahmad Dahlan Yogyakarta ${ }^{1)}$, Universitas Negeri Yogyakarta ${ }^{2)}$ \\ rahmi.munfangati@gmail.com ${ }^{1)}$, prat_wid@yahoo.com ${ }^{2)}$
}

\begin{abstract}
Abstrak
Penelitian ini bertujuan untuk mengetahui kinerja guru bahasa Inggris bersertifikat pendidik ditinjau dari: (1) tiap penilai dan tiap kompetensi, (2) latar belakang syarat dan proses sertifikasi (tingkat pendidikan, pengalaman mengajar, jalur sertifikasi), dan untuk mengetahui (3) hambatan-hambatan yang dihadapi guru bahasa Inggris bersertifikat pendidik pascasertifikasi. Penelitian ini menggunakan pendekatan kuantitatif jenis survei. Populasi pada penelitian ini 43 orang guru bahasa Inggris bersertifikat pendidik dari 10 SMA Negeri dan 12 SMA Swasta di Kota Yogyakarta. Instrumen pengumpulan data menggunakan angket dengan penskalaan menggunakan model Likert. Analisis data yang digunakan adalah analisis deskriptif. Hasil analisis deskriptif menunjukkan bahwa (1) ditinjau dari penilai dan kompetensi, guru memiliki kinerja pada kategori baik; (2) guru yang memiliki tingkat pendidikan tinggi, pengalaman kerja tinggi, dan lulus sertifikasi melalui uji portofolio memiliki kinerja pada kategori sangat baik; dan (3) terdapat dua faktor yang menjadi hambatan guru bahasa Inggris SMA bersertifikat pendidik pascasertifikasi, yaitu faktor internal dan faktor eksternal.
\end{abstract}

Kata kunci: Kinerja guru, tingkat pendidikan, pengalaman mengajar, jalur sertifikasi

\section{THE PERFORMANCE OF CERTIFIED ENGLISH TEACHERS IN YOGYAKARTA REGENCY}

\begin{abstract}
This study aims to reveal the performance of certified English teachers reviewed by (1) each rater and each competence, (2) background as requirements dan process of certification (education levels, teaching experiences, the path of teacher certification), and to reveal (3) the obstacles faced by certified English teachers post-certification. This study used quantitative approach which was a survey research study. The populations in this study were 43 certified English teachers who teach at 10 Public Senior High Schools and 12 Private Senior High Schools in Yogyakarta. The instruments of the data collection were questionnaires using Likert scaling model. The data were analyzed using the descriptive analysis. The results of the study show the following. (1) The performance of the teachers reviewed by each rater and each competence show a good achievement. (2) Teachers who have higher levels of education, higher work experiences, and passed certification through portfolio assessment have an excellent performance. (3) There are two factors that become barriers to certified English teachers of Senior High School post-certification, i.e. internal factors and external factors.
\end{abstract}

Keywords: Performance of teachers, levels of education, teaching experience, path of certification 


\section{PENDAHULUAN}

Menurut laporan pembangunan manusia tahun 2011 yang dikeluarkan UNDP, Indeks Pembangunan Manusia (IPM) Indonesia berada di peringkat 124 dari 187 negara yang tercatat, sebagaimana dikutip oleh Sardjunani (2012, p.1), yaitu sebagai berikut. Pada tahun 2011 UNDP memasukan 187 negara dan Indonesia berada pada peringkat ke-124. Pada 1980 IPM Indonesia dilaporkan 0,423 dan pada 2011 telah meningkat menjadi 0,617 atau tumbuh 1,17 persen. IPM Indonesia pada 2010 tercatat lebih rendah yaitu 0,613. Lebih khusus, Indeks Pendidikan Indonesia pada tahun 2011 dilaporkan 0,584 dan berada pada peringkat 119 dari 187 negara, sama dengan Indeks Pendidikan Indonesia pada tahun 2010. Dengan indikator tersebut, bisa dikatakan bahwa meskipun IPM Indonesia meningkat, dalam skala global kualitas pendidikan Indonesia masih di bawah negaranegara tetangga. Oleh karena itu, pemerintah terus berupaya untuk meningkatkan kinerja pembangunan manusia Indonesia, termasuk aspek pendidikan.

Pemerintah terus berupaya meningkatkan kinerja pembangunan manusia Indonesia dari aspek pendidikan dengan mengembangkan kebijakan yang mendorong keberadaan guru yang berkualitas. Seiring dengan tuntutan untuk meningkatkan mutu pendidikan di setiap satuan pendidikan, dari sekian banyak komponen pendidikan, guru merupakan faktor yang sangat penting dan strategis. Guru merupakan garda terdepan yang berhadapan langsung dan berinteraksi dengan siswa dalam proses belajar mengajar sehingga bisa dikatakan guru ikut berperan dalam menciptakan sumber daya manusia yang berkualitas. Sebanyak apapun investasi yang ditanamkan untuk memperbaiki mutu pendidikan, tanpa kehadiran guru yang profesional dengan segala kompetensi yang dimiliki, maka tujuan yang diharapkan tidak akan tercapai. Keberadaan guru yang bermutu merupakan syarat mutlak hadirnya sistem dan praktik pendidikan yang berkualitas.

Kualitas pendidikan dikatakan bagus apabila kegiatan belajar mengajar pun bagus. Kegiatan belajar mengajar bagus seiring dengan peningkatan kinerja guru. Salah satu bentuk upaya peningkatan kinerja guru dari pemerintah adalah dengan meningkatkan jaminan dan kesejahteran hidup guru yang memadai melalui sertifikasi. Merujuk pada ketentuan Pasal 42 ayat (1) Undang-Undang Nomor 20 Tahun 2003 tentang Sistem Pendidikan Nasional, disebutkan bahwa pendidik harus memiliki kualifikasi minimum dan sertifikasi sesuai dengan jenjang kewenangan mengajar, sehat jasmani dan rohani, serta memiliki kemampuan untuk mewujudkan tujuan pendidikan nasional. Pelaksanaan sertifikasi guru dimulai pada tahun 2007 setelah diterbitkannya Peraturan Menteri Pendidikan Nasional Nomor 18 Tahun 2007 tentang Setifikasi bagi Guru dalam Jabatan. Tahun 2011 merupakan tahun kelima pelaksanaan sertifikasi bagi guru dalam jabatan. Landasan yang digunakan sebagai dasar penyelenggaraan sertifikasi guru tahun 2011 adalah Peraturan Menteri Pendidikan Nasional Nomor 11 Tahun 2011. Pasal 4 ayat (2) dalam Peraturan Menteri tersebut menyebutkan bahwa sertifikasi diikuti oleh guru dalam jabatan yang: (1) memiliki kualifikasi akademik sarjana (S-1) atau diploma empat (D-IV), (2) belum memenuhi kualifikasi akademik S-1 atau D-IV apabila sudah mencapai usia 50 tahun dan mempunyai pengalaman kerja 20 tahun sebagai guru; atau mempunyai golongan IV/a, atau yang memenuhi angka kredit kumulatif setara dengan golongan IV/a, (3) telah diangkat menjadi guru sebelum tanggal 30 Desember 2005.

Proses sertifikasi ini adalah dengan mengikuti uji kompetensi untuk mendapatkan sertifikat profesi guru, tidak terkecuali guru mata pelajaran bahasa Inggris. Dengan terlaksananya sertifikasi guru, diharapkan akan berdampak pada meningkatnya kualitas kinerja guru seiring dengan meningkatnya mutu pembelajaran dan mutu pendidikan secara berkelanjutan karena adanya peningkatan kesejahteraan mereka sebagaimana dikemukakan Samani dkk (2006, p.4) melalui Gambar 1 berikut.

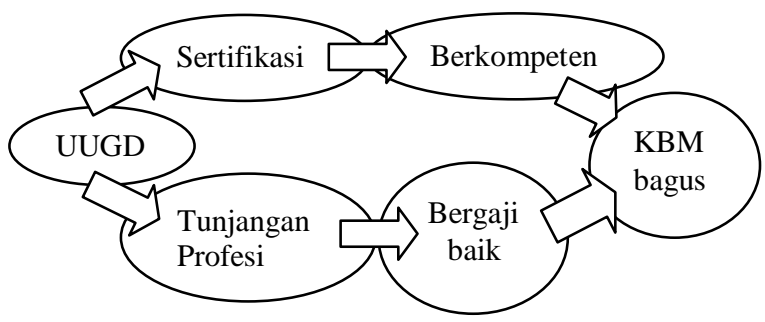

Gambar 1. Keberadaan Sertifikasi dalam Meningkatkan Kualitas Pendidikan (Samani, 2007, p.17)

Adanya sertifikasi, guru sebagai tenaga profesional dapat meningkatkan martabatnya dan guru sebagai agen pembelajaran dapat meningkatkan mutu pendidikan nasional. Dalam Undang-Undang Nomor 14 Tahun 2005 tentang Guru dan Dosen pasal 1 ayat (4) didefinisikan 
bahwa profesional adalah pekerjaan atau kegiatan yang dilakukan oleh seseorang dan menjadi sumber penghasilan kehidupan yang memerlukan keahlian, kemahiran, atau kecakapan yang memenuhi standar mutu atau norma tertentu serta memerlukan pendidikan profesi. Dengan demikian, guru adalah pekerja profesional yang mendapatkan hak sekaligus kewajiban profesional dapat mengabdikan secara total pada profesinya dan dapat hidup layak dari profesi tersebut. Dengan sertifikat pendidik, yang diperoleh setelah melalui uji sertifikasi maka seorang guru berhak memperoleh penghasilan di atas kebutuhan hidup minimum dan jaminan kesejahteraan sosial, sebagaimana tercantum dalam pasal 14 ayat (1) huruf a. Lebih lanjut dijelaskan pada pasal 15 ayat (1) bahwa penghasilan di atas kebutuhan hidup minimum meliputi gaji pokok, tunjangan yang melekat pada gaji, serta penghasilan lain berupa tunjangan profesi, tunjangan fungsional, tunjangan khusus, dan maslahat tambahan yang terkait dengan tugasnya sebagai guru yang ditetapkan dengan prinsip penghargaan atas dasar prestasi.

Sertifikat pendidik kemudian menjadi bukti formal atas pengakuan yang diberikan kepada guru sebagai tenaga profesional, melalui dua jalur yaitu portofolio atau Pendidikan dan Latihan Profesi Guru (PLPG). Hal ini mengandung arti bahwa pekerjaan guru hanya dapat dilakukan oleh seseorang yang mempunyai kualifikasi akademik, kompetensi, dan sertifikat pendidik yang sesuai dengan persyaratan untuk setiap jenis dan jenjang pendidikan tertentu.

Dalam Peraturan Pemerintah No. 16 Tahun 2007 tentang Standar Kualifikasi Akademik dan Kompetensi Guru tertanggal 4 Mei 2007 disebutkan bahwa standar kompetensi guru dikembangkan secara utuh dari empat kompetensi utama, yaitu kompetensi pedagogik, kompetensi kepribadian, kompetensi sosial, dan kompetensi profesional. Keempat kompetensi tersebut terintegrasi dalam kinerja guru. Dengan demikian, apabila salah satu kompetensi ditinggalkan maka secara otomatis kinerja guru dalam melaksanakan profesinya sebagai pendidik tidak terpenuhi.

Secara teoritis, integrasi keempat kompetensi tersebut sebagai bentuk kinerja guru seharusnya tercermin pada kepatuhan dan loyalitasnya di dalam menjalankan tugas keguruannya di dalam kelas dan tugas kependidikannya di luar kelas; rasa tanggung jawabnya mempersiapkan segala perlengkapan pengajaran sebelum melaksanakan proses pembelajaran; dan mempertimbangkan metodologi yang akan diguna- kan, termasuk alat media pendidikan yang akan dipakai serta alat penilaian apa yang akan digunakan di dalam pelaksanaan evaluasi. Oleh karena itu, perlu adanya kesadaran dan pemahaman dari semua pihak bahwa sertifikasi adalah sarana untuk menuju kualitas. Sertifikasi bukan tujuan itu sendiri. Kesadaran dan pemahaman ini akan melahirkan aktivitas yang benar bahwa apapun yang dilakukan adalah untuk mencapai kualitas. Demikian pula guru mata pelajaran bahasa Inggris yang mengikuti uji sertifikasi, tujuan utamanya bukan untuk mendapatkan tunjangan profesi, melainkan untuk dapat menunjukkan bahwa yang bersangkutan telah memiliki kompetensi sebagaimana disyaratkan dalam standar kemampuan guru.

Masalah utama dalam penelitian ini adalah belum diketahuinya kinerja guru yang sudah lulus sertifikasi. Sedangkan tujuannya adalah (1) mendeskripsikan kinerja guru bahasa Inggris bersertifikat pendidik di Kota Yogyakarta ditinjau dari penilai dan kompetensi, (2) mendeskripsikan kinerja guru bahasa Inggris bersertifikat pendidik di Kota Yogyakarta berdasarkan latar belakang/syarat dan proses sertifikasi, dan (3) mengetahui hambatan-hambatan yang dihadapi guru bahasa Inggris bersertifikat pendidik di Kota Yogyakarta. Diharapkan hasil penelitian ini mampu menjadi tambahan wawasan tentang kajian terhadap kinerja guru bahasa Inggris bersertifikat pendidik di lingkup SMA Negeri dan Swasta se-Kota Yogyakarta dan sebagai dasar pijakan awal bagi penelitian-penelitian lain yang sejenis. Selain itu juga diharapkan, hasil penelitian mampu menjadi rekomendasi dan refleksi dalam melaksanakan kebijakan pendidikan dan mengevaluasi pelaksanaan sertifikasi yang akan datang.

\section{Kinerja Guru}

Istilah kinerja dalam bahasa Inggris adalah "performance" diartikan sebagai "notable action: achievement" (Honby, 1987, p.623), yang berarti "prestasi yang diperlihatkan: kemampuan kerja". Dengan demikian secara konseptual kinerja dapat diterjemahkan sebagai prestasi kerja, penampilan kerja, ketepatan kerja, dan produktivitas kerja. Dengan kalimat lain, kinerja merupakan unjuk kerja yang tampak dan dapat diamati sebagai manifestasi dari prestasi kerja.

Menurut Mangkuprawira dan Vitayala (Yamin dan Maisah, 2010, p.129), kinerja merupakan suatu kontruksi multidimensi yang mencakup banyak faktor yang mempengaruhi- 
nya (faktor intrinsik guru: personal/individual atau SDM dan faktor ekstrinsik guru: kepemimpinan, sistem, tim, dan situasional). Dengan demikian, dapat diartikan bahwa kinerja merupakan prestasi kerja yang dilakukan seseorang dalam aktivitasnya, yang dipengaruhi oleh beberapa faktor.

Dari pengertian tersebut, dapat dipahami bahwa kinerja merupakan prestasi kerja dalam melakukan suatu pekerjaan atau proses yang mengarah kepada suatu hasil yang diharapkan dengan segenap daya upaya dan dipengaruhi beberapa faktor berkenaan dengan segala macam tugas dan kewajiban yang harus dilaksanakan dalam mencapai tujuan yang diharapkan oleh organisasi tempat dia bekerja. Kinerja dihubungkan dengan keberadaan seorang guru yang menjadi ujung tombak pendidikan. Alhasil, kinerja seorang guru banyak sekali pengaruhnya dengan proses belajar yang terjadi di dalam maupun di luar kelas.

Menurut Waluyo (2011, p.8), kinerja guru itu berhubungan dengan berbagai aktivitas guru dalam proses instruksional yang berkaitan dengan tanggung jawab dan tugas guru. Dengan demikian, dapat disimpulkan kinerja guru bahasa Inggris adalah penampilan seorang guru bahasa Inggris dalam memangku jabatannya. Kinerja guru bahasa Inggris adalah kemampuan yang dimiliki oleh guru bahasa Inggris yang peranannya sangat penting di dalam pelaksanaan proses pembelajaran bahasa Inggris. Kinerja guru bahasa Inggris yang paling pokok adalah pengelolaan proses pembelajaran bahasa Inggris. Kinerja guru bahasa Inggris dalam pengelolaan proses pembelajaran bahasa Inggris ini merupakan kunci keberhasilan yang paling dasar untuk membuat siswa belajar bahasa Inggris lebih optimal. Selain itu, kinerja guru dalam menggunakan metode mengajar dan pengelolaan kelas (classroom management) juga sangat mendukung dalam proses pembelajaran bahasa Inggris.

Guru bahasa Inggris harus memilki kemampuan dalam mengelola proses pembelajaran bahasa Inggris. Kemampuan guru bahasa Inggris dalam mengelola proses pembelajaran bahasa Inggris ini dapat diartikan suatu pengetahuan yang dimiliki oleh guru bahasa Inggris atau cara guru bahasa Inggris untuk menyampaikan informasi di dalam pembelajaran, khususnya pembelajaran bahasa Inggris sehingga belajar bahasa Inggris dapat berlangsung walaupun tanpa didampingi guru, sebagaimana didefinisikan oleh Triyono, Kartowagiran, Retnowati (2012, p.1) bahwa kinerja guru adalah penampil- an guru terkait dengan kompetensi profesional, pedagogi, sosial, dan kompetensi kepribadian guru.

Kemudian, untuk mengevaluasi kinerja guru dilakukan penilaian kinerja. Penilaian kinerja mencerminkan kondisi nyata, tidak seperti penilaian tradisional (tes tertulis) (Reynolds, Livingston, dan Wilson, 2010, p.247). Menurut Blerkom (2009, pp.156-157), penilaian kinerja bisa digunakan untuk mengukur proses maupun hasil. Penilaian kinerja ini biasanya menggunakan angket berupa checklist, skala pengukuran, dan rubrik.

\section{Kompetensi Guru}

Undang-undang Republik Indonesia No. 14 Tahun 2005 tentang Guru dan Dosen 1 ayat (10) menjelaskan bahwa "kompetensi adalah seperangkat pengetahuan, keterampilan dan perilaku yang harus dimiliki, dihayati dan dikuasai oleh guru atau dosen dalam melaksanakan tugas keprofesionalan". Kemudian, Mulyasa (2007, p.26) menerangkan bahwa kompetensi guru menunjuk pada kinerja dan perbuatan yang rasional untuk memenuhi spesifikasi tertentu di dalam pelaksanaan tugas-tugas kependidikan. Dikatakan rasional karena mempunyai arah dan tujuan, sedangkan kinerja merupakan perilaku nyata dalam arti tidak hanya dapat diamati, tetapi mencakup sesuatu yang tidak kasat mata. Kompetensi merupakan komponen utama dari standar profesi di samping kode etik sebagai regulasi perilaku profesi yang ditetapkan dalam prosedur dan sistem pengawasan tertentu.

Menurut Peraturan Pemerintah Republik Indonesia No. 19 Tahun 2005 tentang Standar Nasional Pendidikan Pasal 28, pendidik (guru) adalah agen pembelajaran yang harus memiliki empat jenis kompetensi, yakni kompetensi pedagogik, kepribadian, profesional, dan sosial. Dalam konteks itu, maka kompetensi guru dapat diartikan sebagai kebulatan pengetahuan, keterampilan dan sikap yang diwujudkan dalam bentuk perangkat tindakan cerdas dan penuh tanggung jawab yang dimiliki seseorang calon guru untuk memangku jabatan guru sebagai profesi.

Kompetensi guru merupakan perpaduan antara kemampuan personal, keilmuan, teknologi, sosial dan spiritual yang secara menyeluruh membentuk kompetensi standar profesi guru, yang mencakup penguasaan materi, pemahaman terhadap peserta didik, pembelajaran yang mendidik, pengembangan pribadi dan profesionalisme. Menurut Majid dalam Yamin dan Maisah 
(2010, p.7), "standar kompetensi guru adalah suatu ukuran yang ditetapkan atau dipersyaratkan dalam bentuk penguasaan pengetahuan dan berperilaku layaknya seorang guru untuk menduduki jabatan fungsional sesuai bidang tugas, kualifikasi dan jenjang pendidikan".

"Standar kompetensi dalam program sertifikasi lebih menekankan pada pemberian kompetensi minimal yang dipersyaratkan untuk melakukan unjuk kerja yang efektif di tempat tugas. Tempat tugas dalam program ini adalah tugas kependidikan" (Mulyasa, 2007, p.32).

Berdasarkan penjelasan pada Peraturan Menteri Pendidikan Nasional Republik Indonesia No. 16 tahun 2007 tentang Standar Kualifikasi Akademik dan Kompetensi Guru, bahwasanya "standar kompetensi guru dikembangkan secara utuh dari empat kompetensi utama, yaitu: (1) kompetensi pedagogik, (2) kompetensi kepribadian, (3) kompetensi sosial, dan (4) kompetensi profesional". Lebih lanjut, Peraturan Pemerintah Republik Indonesia Nomor 19 Tahun 2005 tentang Standar Nasional Pendidikan dalam penjelasan pasal 28 ayat (3) menjabarkan definisi masing kompetensi sebagai berikut. Kompetensi pedagogis adalah kemampuan mengelola pembelajaran peserta didik yang meliputi pemahaman terhadap peserta didik, perancangan dan pelaksanaan pembelajaran, evaluasi hasil belajar, dan pengembangan peserta didik untuk mengaktualisasikan berbagai potensi yang dimilikinya. Kompetensi kepribadian adalah kemampuan kepribadian yang mantap, stabil, dewasa, arif, dan berwibawa, menjadi teladan bagi peserta didik, dan berakhlak mulia. Kompetensi profesional adalah kemampuan penguasaan materi pembelajaran secara luas dan mendalam yang memungkinkannya membimbing peserta didik memenuhi standar kompetensi yang ditetapkan dalam Standar Nasional Pendidikan. Kompetensi sosial adalah kemampuan pendidik sebagai bagian dari masyarakat untuk berkomunikasi dan bergaul secara efektif dengan peserta didik, sesama pendidik, tenaga kependidikan, orangtua/wali peserta didik, dan masyarakat sekitar.

Empat kompetensi tersebut pada dasarnya tidak terpisah secara ekplisit, tetapi menyatu menjadi suatu kompetensi guru. Hal lain yang perlu diperhatikan adalah kompetensi seseorang adakalanya mengembang tetapi adakalanya menurun. Untuk itu, guru harus selalu berusaha untuk meningkatkan kompetensinya.

\section{METODE}

\section{Jenis Penelitian}

Sesuai dengan judul dan permasalahan penelitian serta tujuan yang ingin dicapai, penelitian ini menggunakan pendekatan kuantitatif. Penelitian ini merupakan jenis penelitian survei, mengingat hanya mendeskripsikan/menggambarkan deskripsi kondisi obyek penelitian, tanpa melakukan manipulasi/memberi treatment pada objek tersebut. Adapun objek penelitian ini adalah kinerja guru bahasa Inggris beserta komponen-komponen yang terdapat didalamnya.

\section{Waktu dan Tempat Penelitian}

Penelitian ini dilaksanakan selama satu tahun lima bulan dimulai bulan Juli 2011 sampai dengan Oktober 2012, dimulai dari pengajuan proposal, penyusunan instrumen yang diperlukan, tahap pengumpulan data, yang dilanjutkan dengan pengolahan data dan penyusunan laporan hasil penelitian. Penelitian ini dilaksanakan di SMA Kota Yogyakarta, baik yang berstatus negeri maupun swasta Provinsi Daerah Istimewa Yogyakarta.

\section{Target/Subjek Penelitian}

Populasi pada penelitian ini adalah semua guru bahasa Inggris bersertifikat pendidik yang melaksanakan tugas mengajar di SMA Kota Yogyakarta. Jumlah guru bahasa Inggris bersertifikat pendidik yang bertugas di 10 SMA Negeri dan 12 SMA Swasta Kota Yogyakarta adalah 43 orang. Sejumlah guru tersebut merupakan populasi dalam penelitian ini.

Mengingat jumlah subjek penelitian yang tidak terlalu besar, area penelitian yang relatif terjangkau, dan yang paling mendasar dalam rangka memperoleh data yang valid dan komprehensif, maka semua subjek penelitian tersebut dijadikan sebagai sasaran pengumpulan data. Dengan demikian, penelitian ini merupakan penelitian populasi, artinya semua subjek penelitian dijadikan sebagai sasaran untuk pengumpulan data.

\section{Prosedur}

Penelitian ini tergolong survei yang bermaksud mendeskripsikan kinerja guru bahasa Inggris di Kota Yogyakarta. Kinerja guru bahasa Inggris SMA bersertifikat pendidik di Kota Yogyakarta dalam penelitian ini ditinjau dari penilai dan empat aspek penilaian, yaitu: aspek kompetensi, latar belakang pendidikan, pengalaman mengajar, dan jalur sertifikasi. Data menge- 
nai kinerja guru melalui aspek kompetensinya bersumber dari penilaian guru itu sendiri (self assessment), Kepala Sekolah, dan siswa yang dikumpulkan menggunakan instrumen berupa angket (skala). Data mengenai aspek lain sebagai tinjauannya, seperti: latar belakang pendidikan, pengalaman mengajar, dan jalur sertifikasi bersumber dari angket dan dokumen.

Tingkat kinerja guru diukur melalui penghitungan persentase skor perolehan (empirik) dibandingkan dengan skor harapan (ideal), yang kemudian dikategorisasi berdasarkan panduan. Data yang telah dikumpulkan selanjutnya dideskripsikan berdasarkan tujuan penelitian, yaitu mendeskripsikan kinerja guru bahasa Inggris bersertifikat pendidik di Kota Yogyakarta ditinjau dari penilai (guru itu sendiri, Kepala Sekolah, dan siswa) dan kompetensi (kompetensi pedagogik, kompetensi kepribadian, kompetensi sosial, dan kompetensi profesional), mendeskripsikan kinerja guru bahasa Inggris bersertifikat pendidik di Kota Yogyakarta berdasarkan latar belakang/syarat dan proses sertifikasi (tingkat pendidikan, pengalaman mengajar, dan jalur sertifikasi), dan mengetahui hambatan-hambatan yang dihadapi guru bahasa Inggris bersertifikat pendidik di Kota Yogyakarta.

\section{Data, Intrumen, dan Teknik Pengumpulan Data}

Data kinerja guru diperoleh melalui aspek kompetensinya bersumber dari penilaian guru itu sendiri (self assessment), Kepala Sekolah, dan siswa yang menggunakan instrumen berupa angket (skala) sebagai teknik pengumpulan data. Data mengenai aspek lain sebagai tinjauannya, seperti tingkat pendidikan, pengalaman mengajar, dan jalur sertifikasi bersumber dari instrumen berupa angket dan dokumen.

Pengembangan kisi-kisi instrumen dalam penelitian ini dikembangkan berdasarkan dari kajian teori dari bab sebelumnya. Instrumen untuk mengukur variabel Kinerja Guru berupa kuesioner yang terdiri dari 67 pernyataan untuk penilai guru, 44 pernyataan untuk penilai Kepala Sekolah, dan 51 pernyataan untuk penilai siswa. Angket tersebut menggunakan empat alternatif jawaban yaitu Tidak Setuju (TS), Kurang Setuju (KS), Setuju (S), dan Sangat Setuju (SS). Pemberian skor alternatif jawaban tersebut berdasarkan criteria penilaian, yaitu: SS dengan skor 4, S dengan skor 3, KS dengan skor 2, dan TS dengan skor 1 .

Instrumen penilaian diri guru bahasa Inggris bersertifikat pendidik diadopsi dari
Common European Framework of Reference for Language Learning, Teaching and Assessment level C1 dan C2 (Little, 2006, pp.170-172). Instrumen untuk mengukur variabel Kinerja Guru melalui penilaian diri berupa kuesioner yang terdiri dari 60 pernyataan dengan empat alternative jawaban yaitu Tidak Setuju (1), Kurang Setuju (2), Setuju (3), dan Sangat Setuju (4). Pemberian skor alternative jawaban tersebut berdasarkan kriteria penilaian, yaitu: Sangat Setuju dengan skor 4, Setuju dengan skor 3, Kurang Setuju dengan skor 2, dan Tidak Setuju dengan skor 1.

\section{Teknik Analisis Data}

Seperti yang telah diuraikan di atas, penelitian ini merupakan penelitian jenis survei dengan pendekatan kuantitatif dan análisis data yang digunakan adalah analisis deskriptif. Analisis data deskriptif kuantitatif untuk mendeskripsikan kinerja guru bahasa Inggris bersertifikat pendidik. Berdasarkan analisis tersebut, instrumen penelitian berguna untuk memperoleh data numerikal. Tabulasi data untuk masingmasing variabel dilakukan terhadap skor yang diperoleh. Selanjutnya, dengan bantuan komputer menggunakan program SPSS v.19 for Windows diperoleh rerata, modus, nilai maksimal, nilai minimal, stándar deviasi, dan variasi untuk setiap variabel penelitian, yaitu variabel kinerja guru bahasa Inggris bersertifikat pendidik, dengan komponen kompetensi pedadogik, kompetensi kepribadian, kompetensi sosial, kompetensi profesional, sebagai variabel dependen. Sedangkan, variabel independen adalah pengalaman mengajar, tingkat pendidikan, dan jalur sertifikasi.

Hasil penilaian oleh guru, Kepala Sekolah, dan siswa dikelompokkan/dikategorikan dalam lima kategori. Adapun lima kategori hasil pengelompokan sebagaimana yang dikemukakan oleh Azwar (2012, p.148) ditetapkan seperti pada Tabel 1 berikut.

Tabel 1. Kategorisasi Penilaian

\begin{tabular}{cc}
\hline Rentang Skor & Tingkat Kategori \\
\hline $\mathrm{Mi}+1,5 \mathrm{Sdi}<\mathrm{X}$ & Sangat Baik \\
$\mathrm{Mi}+0,5 \mathrm{Sdi}<\mathrm{X} \leq \mathrm{Mi}+1,5 \mathrm{Sdi}$ & Baik \\
$\mathrm{Mi}-0,5 \mathrm{Sdi}<\mathrm{X} \leq \mathrm{Mi}+0,5 \mathrm{Sdi}$ & Cukup \\
$\mathrm{Mi}-1,5 \mathrm{Sdi}<\mathrm{X} \leq \mathrm{Mi}-0,5 \mathrm{Sdi}$ & Kurang Baik \\
$\mathrm{X} \leq \mathrm{Mi}-1.5 \mathrm{Sdi}$ & Sangat Kurang \\
\hline
\end{tabular}

Keterangan:

$X=$ Skor responden

$M \mathrm{i}=$ Rerata atau mean ideal

Sdi $=$ Standar deviasi ideal 
Pada penelitian ini, analisis statistik deskriptif digunakan bantuan komputer program SPSS.19 for windows yang kemudian hasilnya dikonsultasikan dengan tabel di atas untuk mendeskripsikan variabelnya.

\section{HASIL DAN PEMBAHASAN}

Kriteria kinerja guru dalam penelitian ini didasarkan pada indikator kompetensi guru yang tingkatannya diperoleh melalui penghitungan persentase skor perolehan (empirik) yang kemudian dibandingkan dengan skor harapan (ideal). Berikut ini panduan kategorisasi dalam penilaian kinerja guru.

Tabel 2. Panduan Kategorisasi Penilaian Kinerja Guru

\begin{tabular}{ccc}
\hline No & $\begin{array}{c}\text { Rentang Persentase } \\
\text { Pencapaian (\%) }\end{array}$ & $\begin{array}{c}\text { Tingkat Kategori } \\
\text { Penilian }\end{array}$ \\
\hline 1 & $81,25-100,00$ & Sangat Baik (SB) \\
2 & $68,74-81,24$ & Baik (B) \\
3 & $56,25-68,74$ & Cukup (C) \\
4 & $43,75-56,24$ & Kurang Baik (KB) \\
5 & $00,00-43,74$ & Sangat Kurang (SK) \\
\hline
\end{tabular}

\section{Kinerja Guru Bahasa Inggris Bersertifikat Pendidik di Kota Yogyakarta Ditinjau dari Penilai}

Kinerja guru bahasa Inggris SMA bersertifikat pendidik di Kota Yogyakarta ditinjau dari penilai pada umumnya dalam kategori baik. Hal tersebut berdasarkan hasil perbandingan total keseluruhan kompetensi guru yang ditinjau dari masing-masing penilai. Total keseluruhan kompetensi ini diperoleh dari skor gabungan atau skor rata-rata hasil penilaian dari diri sendiri, Kepala Sekolah, dan siswa.

Jika ditinjau dari diri sendiri maka pencapaian kompetensi guru menunjukkan pencapaian $82,63 \%$ yang berarti sangat baik. Hal ini berbeda dengan pencapaian kompetensi guru ditinjau dari Kepala Sekolah yang menunjukkan pencapaian $80,25 \%$ yang berarti baik. Demikian pula dengan kompetensi guru yang ditinjau dari siswa yang menunjukkan pencapaian $77,85 \%$ yang berarti baik. Rangkuman dari kompetensi guru ditinjau dari tiap penilai dapat dilihat dalam Tabel 3 berikut ini.
Tabel 3. Deskripsi Kinerja Guru Ditinjau Penilai

\begin{tabular}{llcc}
\hline Komponen & Penilai & $\begin{array}{c}\text { Pencapaian } \\
(\mathbf{\%})\end{array}$ & Ket \\
\hline \multirow{3}{*}{ Pedagogik } & Guru & 83,45 & SB \\
& Kepsek & 80,74 & B \\
& Siswa & 76,70 & B \\
\hline \multirow{3}{*}{ Kepribadian } & Guru & 83,31 & SB \\
& Kepsek & 81,98 & SB \\
& Siswa & 79,52 & B \\
\hline \multirow{3}{*}{ Sosial } & Guru & 82,56 & SB \\
& Kepsek & 78,56 & B \\
& Siswa & 81,13 & B \\
\hline \multirow{3}{*}{ Profesional } & Guru & 76,11 & B \\
& Kepsek & 78,27 & B \\
& Siswa & 75,36 & B \\
\hline \multirow{2}{*}{ Total } & Guru & 81,36 & SB \\
& Kepsek & 80,46 & B \\
& Siswa & 77,85 & B \\
\hline
\end{tabular}

Kompetensi pedagogik guru jika ditinjau dari diri sendiri menunjukkan pencapaian $83,45 \%$ yang berarti sangat baik, jika ditinjau dari Kepala Sekolah menunjukkan pencapaian 79,58\% yang berarti baik, dan jika ditinjau dari siswa menunjukkan pencapaian $76,70 \%$ yang berarti baik. Kemudian, kompetensi kepribadian guru jika ditinjau dari diri sendiri menunjukkan pencapaian $83,31 \%$ yang berarti sangat baik, jika ditinjau dari Kepala Sekolah menunjukkan pencapaian $81,98 \%$ yang berarti baik, dan jika ditinjau dari siswa menunjukkan pencapaian $79,52 \%$ yang berarti sangat baik.

Untuk kompetensi sosial, menurut diri sendiri menunjukkan pencapaian $82,56 \%$ yang berarti sangat baik. Kemudian, menurut Kepala Sekolah menunjukkan pencapaian $78,56 \%$ yang berarti baik dan menurut siswa menunjukkan pencapaian $81,13 \%$ yang berarti baik.

Hal tersebut berbeda dengan pencapaian kompetensi profesional guru. Menurut diri sendiri, pencapaian kompetensi profesional guru menunjukkan $79,75 \%$ yang berarti baik. Sedangkan, kompetensi profesional guru menurut Kepala Sekolah menunjukkan pencapaian $78,27 \%$ yang berarti baik dan menurut siswa menunjukkan $75,36 \%$ yang berarti baik.

Dilihat dari tiap penilai maka guru menilai diri sendiri memiliki keunggulan kompetensi pedagogik dibandingkan dengan tiga kompetensi yang lain. Hal tersebut berbeda dengan penilaian Kepala Sekolah dan siswa yang lebih dominan menilai bahwa dari keempat kompetensi, guru memiliki keunggulan pada kompetensi kepribadian. Terjadinya perbedaan pandangan tersebut dimungkinkan karena guru cenderung lebih subjektif sehingga secara umum, setelah 
dikalkulasikan, kompetensi tertinggi adalah kompetensi pedagogik. Kepala Sekolah dan siswa berpersepsi lain. Kesamaan hasil penilaian yang hampir mirip ini menunjukkan bahwa Kepala Sekolah dan siswa lebih konsisten. Kemudian, berdasarkan hasil perbandingan kompetensi ditinjau tiap penilai pada Gambar 2, dapat disimpulkan bahwa baik diri sendiri, Kepala Sekolah, maupun siswa menyetujui bahwa kompetensi terendah guru adalah kompetensi profesional.

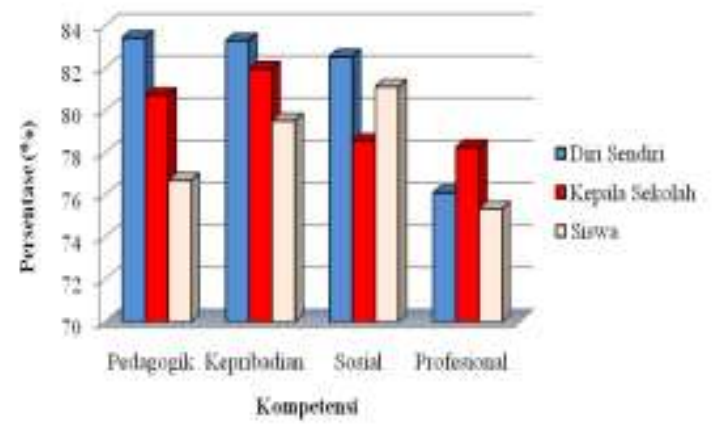

Gambar 2. Kinerja Guru Ditinjau Penilai

Dari total kompetensi yang ditinjau tiap penilai juga dihitung skor gabungan atau skor rata-rata dalam bentuk persentase. Data kemudian menunjukan hasil yang berbeda antara penilaian dari diri sendiri, Kepala Sekolah, dan siswa. Dari 43 orang guru yang dinilai, 2,33\% dinyatakan cukup baik, 53,49\% dinyatakan baik, dan $44,19 \%$ dinyatakan sangat baik. Dengan demikian, kecenderungan penilaian kinerja guru adalah baik, ditunjukkan dalam Tabel 4 sebagai berikut.

Tabel 4. Kategori Kinerja Guru Ditinjau Penilai

\begin{tabular}{ccccc}
\hline Kategori & $\begin{array}{c}\text { Guru } \\
(\boldsymbol{\%})\end{array}$ & $\begin{array}{c}\text { Siswa } \\
(\boldsymbol{\%})\end{array}$ & $\begin{array}{c}\text { Kepsek } \\
(\boldsymbol{\%})\end{array}$ & $\begin{array}{c}\text { Total } \\
(\boldsymbol{\%})\end{array}$ \\
\hline SKB & 0,00 & 0,00 & 0,00 & 0,00 \\
KB & 0,00 & 0,00 & 2,33 & 0,00 \\
CB & 2,33 & 2,70 & 2,33 & 2,33 \\
B & 51,16 & 75,68 & 46,51 & 53,49 \\
SB & 46,51 & 21,62 & 48,84 & 44,19 \\
Total & 100 & 100 & 100 & 100 \\
\hline
\end{tabular}

Kinerja Guru Bahasa Inggris Bersertifikat Pendidik di Kota Yogyakarta Ditinjau dari Kompetensi

Berdasarkan analisis deskriptif, secara umum, penilaian kinerja guru ditinjau dari tiap kompetensi menunjukkan kecenderungan pada kategori baik. Hal ini dibuktikan dari hasil perbandingan dari tiap kompetensi. Dari keempat kompetensi, hanya kompetensi kepribadian yang berada pada kategori sangat baik dengan persentase $81,75 \%$, sedangkan kompetensi pedagogik, kompetensi sosial, dan kompetensi profesional pada kategori baik, yaitu 80,37\%, $80,66 \%$, dan $76,70 \%$.

Demikian pula dengan total keseluruhan kompetensi, kinerja guru dinyatakan dalam kategori baik dengan persentase $79,87 \%$. Dengan demikian, dapat diinterpretasikan bahwa guru bahasa Inggris SMA bersertifikat pendidik di Kota Yogyakarta memiliki keunggulan pada kompetensi kepribadian dan kelemahan pada kompetensi profesional. Rangkuman dari data tersebut ditunjukkan melalui Tabel 5 berikut.

Tabel 5. Kinerja Guru Ditinjau Kompetensi

\begin{tabular}{lccc}
\hline Komponen & M & $\begin{array}{c}\text { Pencapaian } \\
(\boldsymbol{\%})\end{array}$ & Ket \\
\hline Pedagogik & 80,37 & 80,37 & B \\
Kepribadian & 81,75 & 81,75 & SB \\
Sosial & 80,66 & 80,66 & B \\
Profesional & 76,70 & 76,70 & B \\
\multicolumn{1}{c}{ Total } & 79,87 & 79,87 & B \\
\hline
\end{tabular}

Ditinjau dari keseluruhan kompetensi, pada umumnya guru bahasa Inggris SMA bersertifikat pendidik di Kota Yogyakarta mempunyai kompetensi tertinggi pada penilaian diri sendiri, yaitu pada kompetensi pedagogik, kompetensi kepribadian, dan kompetensi sosial. Untuk kompetensi profesional, paling tinggi ditinjau dari sudut Kepala Sekolah. Hal ini dapat dilihat dari persentase kompetensi pedagogik $83,45 \%$ yang berarti Sangat Baik, kompetensi kepribadian $83,31 \%$ yang berarti Sangat Baik, kompetensi sosial $82,56 \%$ yang berarti Sangat Baik, dan kompetensi profesional 78,27\% yang berarti Baik.

Berbeda dengan kompetensi yang dilihat dari sudut siswa. Dari keseluruhan kompetensi, kompetensi pedagogik, kompetensi kepribadian, dan kompetensi profesional merupakan kompetensi terendah. Kompetensi pedagogik menunjukkan persentase $76,11 \%$ yang berarti Baik, kompetensi kepribadian menunjukkan persentase $78,27 \%$ yang berarti Baik, dan kompetensi profesional menunjukkan persentase $75,36 \%$ yang berarti Baik. Untuk kompetensi sosial menunjukkan persentase terendah dari sudut Kepala sosial, yaitu $78,56 \%$ yang berarti Baik.

Secara umum, kompetensi pedagogik, kompetensi kepribadian, dan kompetensi sosial dari tiga penilai pada kategori Baik ke Sangat Baik, sedangkan kompetensi profesional dari tiga penilai cenderung pada kategori Baik. 
Gambar 3 berikut mendeskripsi kinerja guru ditinjau dari kompetensi yang disusun dalam bentuk diagram batang.

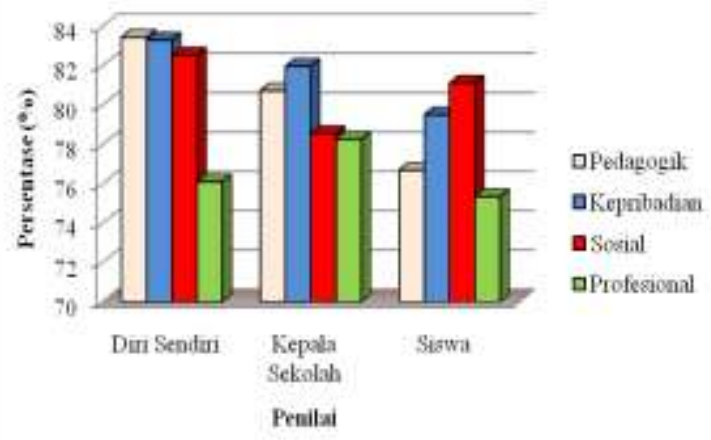

Gambar 3. Kinerja Ditinjau Dari Kompetensi

Skor kinerja guru ditinjau tiap kompetensi kemudian dihitung dalam bentuk persen- tase. Data kemudian menunjukan hasil yang selaras antara kompetensi pedagogik, kompetensi kepribadian, dan kompetensi sosial. Dari ketiga kompetensi tersebut, kecenderungan kinerja guru adalah baik dengan tidak ada guru yang dinyatakan dalam kategori kurang baik. Berbeda dengan kompetensi profesional, meski sebanyak $65,12 \%$ dinyatakan baik, tetapi terdapat $2,33 \%$ yang dinyatakan kurang baik. Namun demikian, dari total keseluruhan kompetensi, kecenderungan penilaian kinerja guru adalah baik. Dari 43 orang guru yang dinilai, 2,33\% dinyatakan cukup baik, 53,49\% dinyatakan baik, dan 44,19\% dinyatakan sangat baik. Data tersebut ditunjukkan dalam Tabel 6 sebagai berikut.

Tabel 6. Kategori Kinerja Guru Ditinjau Kompetensi

\begin{tabular}{cccccc}
\hline Kategori & $\begin{array}{c}\text { Pedagogik } \\
(\boldsymbol{\%})\end{array}$ & $\begin{array}{c}\text { Kepribadian } \\
(\boldsymbol{\%})\end{array}$ & $\begin{array}{c}\text { Sosial } \\
(\boldsymbol{\%})\end{array}$ & $\begin{array}{c}\text { Profesional } \\
(\boldsymbol{\%})\end{array}$ & $\begin{array}{c}\text { Total } \\
(\boldsymbol{\%})\end{array}$ \\
\hline SKB & 0,00 & 0,00 & 0,00 & 0,00 & 0,00 \\
KB & 0,00 & 0,00 & 0,00 & 2,33 & 0,00 \\
CB & 2,33 & 2,33 & 2,33 & 2,33 & 2,33 \\
B & 55,81 & 48,84 & 55,81 & 65,12 & 53,49 \\
SB & 41,86 & 48,84 & 41,86 & 30,23 & 44,19 \\
Total & 100 & 100 & 100 & 100 & 100 \\
\hline
\end{tabular}

\section{Kinerja Guru Ditinjau dari Tingkat Pendidikan}

Tingkat pendidikan guru mempunyai pengaruh terhadap tingkat kinerja guru. Guru bahasa Inggris SMA bersertifikat pendidik di Kota Yogyakarta yang mempunyai tingkat pendidikan yang lebih tinggi cenderung memiliki kinerja yang lebih baik dibandingkan dengan guru yang tingkat pendidikannya lebih rendah. Hal ini dapat dilihat dari persentase kecenderungan bahwa dari 43 guru 9,3\% guru dengan tingkat pendidikan tinggi (S2) mempunyai kinerja yang sangat baik, 7\% mempunyai kinerja baik, dan tidak ada yang memiliki kinerja cukup baik, sedangkan untuk guru dengan tingkat pendidikan rendah (DIII/SM), 2,3\% mempunyai kinerja baik dan tidak ada yang mempunyai kinerja sangat baik. Data tersebut disajikan dalam Gambar 4 sebagai berikut.

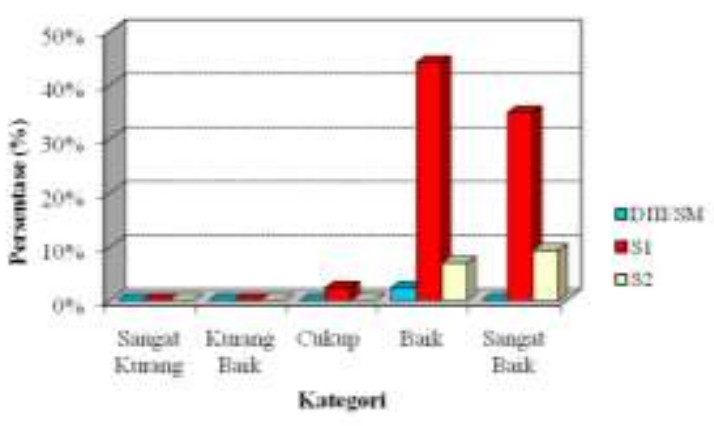

Gambar 4. Tabulasi Silang Antara Tingkat Pendidikan dan Kinerja Guru

\section{Kinerja Guru Ditinjau dari Pengalaman Mengajar}

Dilihat dari pengalaman mengajar maka guru dengan pengalaman mengajar lebih tinggi pada umumnya cenderung mempunyai kinerja yang lebih baik dibandingkan dengan guru yang pengalaman mengajarnya rendah. Hal ini dibuktikan dari persentase kecenderungan $7 \%$ guru yang memiliki pengalaman mengajar tinggi (lebih dari 30 tahun) mempunyai kinerja pada kategori sangat baik dan tidak ada yang mem- 
punyai kinerja cukup baik, sedangkan guru yang mempunyai pengalaman mengajar rendah (kurang dari 10 tahun) hanya mencapai 7\% yang memiliki kinerja pada kategori sangat baik dan sangat baik. Guru yang memiliki pengalaman mengajar antara 20 hingga 29 tahun, 23,3\% pada kategori sangat baik, 25,6\% pada kategori baik, dan 2,3\% pada kategori cukup baik.

Berbeda dengan temuan pada guru yang memiliki pengalaman mengajar antara 10-19 tahun, pada kategori baik mencapai $18,6 \%$ guru dan pada kategori sangat baik hanya $4,7 \%$. Di umur tersebut tidak bisa menjelaskan pengalaman mengajar guru yang lebih tinggi menentukan kinerja guru yang lebih baik pula. Dengan kata lain, di Kota Yogyakarta, kinerja guru lebih rendah pada guru yang memiliki pengalaman mengajar antara 10 sampai 19 tahun. Namun demikian, tetap dapat disimpulkan bahwa tingkat pendidikan adalah aspek yang mempengaruhi kompetensi guru di bidang pendidikan dan pengajaran yang pada akhirnya juga menentukan kinerja guru. Temuan data tersebut kemudian disusun dalam Gambar 5 berikut.

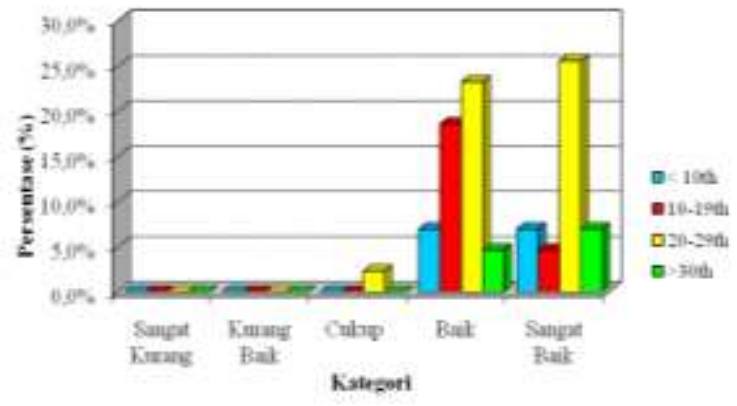

Gambar 5. Tabulasi Silang Antara Pengalaman Mengajar dan Kinerja Guru

\section{Kinerja Guru Ditinjau dari Jalur Sertifikasi}

Jalur sertifikasi seorang guru bersertifikat pendidik juga berperan dalam menentukan tingkat kinerja guru. Hal ini dapat dilihat dari persentase kecenderungan yang menunjukkan bahwa guru yang lulus sertifikasi melalui uji portofolio, 27,9\% memiliki kinerja sangat baik, 23,3\% memiliki kinerja baik, dan tidak ada yang memiliki kinerja cukup baik.

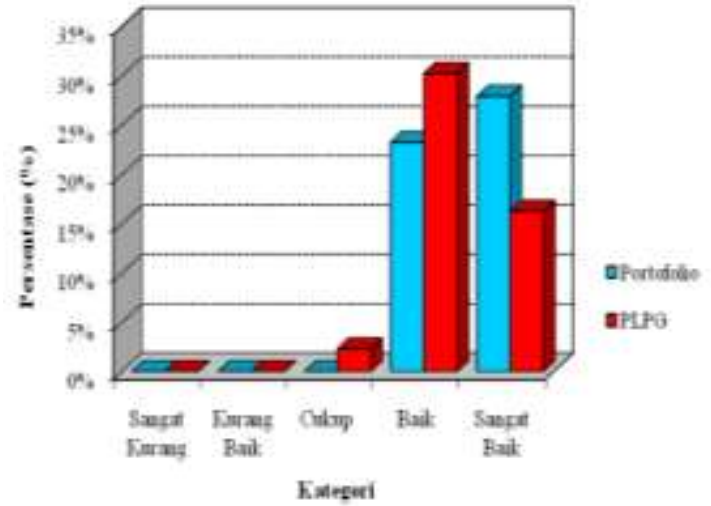

Gambar 6. Kinerja Guru Berdasarkan Jalur Sertifikasi

Untuk guru yang lulus sertifikasi melalui PLPG, hanya $16,3 \%$ yang mempunyai kinerja pada kategori sangat baik dan terdapat 2,3\% yang memiliki kinerja cukup baik. Pada kategori baik, guru yang lulus sertifikasi melalui PLPG mencapai 30,2\%. Dengan demikian, dapat disimpulkan bahwa guru yang lulus melalui uji portofolio mempunyai kinerja yang sedikit lebih unggul dibandingkan dengan guru yang lulus melalui jalur sertifikasi yang lain.

\section{Hambatan-hambatan Pascasertifikasi}

Data dalam penelitian ini juga didapatkan dari angket penelitian yang berupa kuesioner terbuka. Berdasarkan data yang telah dikumpulkan, ditemukan dua faktor yang menjadi hambatan guru bahasa Inggris bersertifikat pendidik di Kota Yogyakarta pascasertifikasi, yaitu: faktor internal dan faktor eksternal guru.

\section{Faktor Internal Guru}

Faktor internal guru merupakan faktor dari dalam guru yang menjadi hambatan guru pascasertifikasi, yakni: beban mengajar, tuntutan administrasi, adanya tugas tambahan, dan penguasaan IPTEK.

\section{Beban Mengajar}

Beberapa guru merasa terbebani dengan jumlah jam yang terlalu banyak, yaitu 24 jam. Dengan adanya beban jam tersebut, beberapa guru merasa kurang bisa menyiapkan materi secara maksimal dan kurang waktu untuk mengembangkan diri. Bahkan, beberapa guru mengeluhkan tidak mempunyai waktu untuk olahraga, refreshing, dan bermasyarakat dikarenakan beban jam tersebut.

Namun demikian, ternyata dengan beban 24 jam tersebut, beberapa guru masih merasa 
kurang cukup. Hal tersebut dibuktikan dengan target terhadap siswa yang masih kurang tepat. Pembelajaran bahasa Inggris bertujuan agar siswa mampu berkomunikasi dalam bahasa Inggris melalui berbagai skill, baik reading, writing, listening, maupun speaking dengan baik sesuai tata bahasa yang benar dan tepat. Pembelajaran bahasa sebenarnya dapat dilaksanakan dengan sempurna apabila siswa maupun guru terbiasa menggunakan bahasa Inggris dalam keseharian masing-masing individu siswa maupun guru. Akan tetapi, pada kenyataannya siswa belajar bahasa Inggris hanya tiap kali tatap muka di dalam kelas. Tatap muka ini berlangsung selama 4 kali dalam satu minggu dengan dua jam tiap tatap muka. Hal ini masih dirasa kurang.

\section{Tuntutan Administrasi}

Beberapa guru juga merasa terbebani dengan tuntutan administrasi guru, misalnya RPP. Beberapa guru menyatakan masih sulitnya memasukkan aspek karakter pada setiap topik. Selain itu, di luar 24 jam tersebut, guru masih memerlukan persiapan mengajar, koreksi tugas siswa, dan tugas luar seperti Penelitian Tindakan Kelas. Hal ini pada akhirnya menyita waktu yang cukup banyak pula.

\section{Adanya Tugas Tambahan}

Beberapa guru merasa kurang optimal dikarenakan adanya tugas tambahan, misalnya sebagai Waka Humas (Wakil Kepala Sekolah Urusan Hubungan Masyarakat).

\section{Penguasaan IPTEK}

Ada guru yang belum dapat menguasai IPTEK dengan baik untuk digunakan dalam KBM (Kegiatan Belajar dan Mengajar). Beberapa guru juga masih kesulitan menyampaikan materi sesuai dengan model pembelajaran yang sekarang.

\section{Faktor Eksternal Guru}

Faktor eksternal guru merupakan faktor dari luar guru yang menjadi hambatan guru pascasertifikasi, yakni: siswa dan prasarana pembelajaran.

\section{Siswa}

Guru mengeluhkan akan sulitnya menemukan cara yang tepat untuk membangkitkan motivasi belajar siswa secara keseluruhan. Siswa tidak suka membaca, tidak suka menerapkan tiap ilmu yg sudah dipelajari. Selain itu, siswa cenderung lebih suka menggunakan bahasa gaul dan cenderung menterjemahkan bahasa Indonesia ke bahasa Inggris dengan tata bahasa, tata kalimat, dan pilihan kata yang kurang tepat.

Siswa juga tidak selalu memahami maksud yang disampaikan guru dalam bahasa Inggris sehingga guru harus selalu menggunakan bahasa campuran (Inggris dan Indonesia). Hal tersebut dikarenakan penguasaan kosa kata siswa masih kurang.

Hal lain yang menghambat proses KBM adalah jumlah siswa yang terlalu banyak dengan kemampuan yang beragam sehingga guru harus memberikan penjelasan berulang kali agar materi tersampaikan dengan baik. Selain itu, guru juga mengampu level kelas yang berbeda sehingga cukup menyita waktu dan tenaga yang cukup banyak menyiapkan materi untuk mendapatkan hasil yang maksimal.

\section{Prasarana Pembelajaran}

Beberapa prasarana yang dianggap masih kurang diantaranya adalah media pembelajaran, LCD, speaker, laboratorium bahasa. Kurang memadainya prasarana pembelajaran bahasa Inggris ini cukup menghambat KBM terutama materi listening.

\section{SIMPULAN}

Berdasarkan hasil analisis data dan pembahasan hasil penelitian dapat diambil kesimpulan sebagai berikut. Berdasarkan hasil deskripsi data dapat diketahui bahwa guru bahasa Inggris SMA bersertifikat pendidik di Kota Yogyakarta pada umumnya cenderung memiliki kinerja guru yang baik. Hal ini dapat dibuktikan dari: (a) Kecenderungan kinerja guru ditinjau dari tiap penilai menunjukkan hasil bahwa kinerja guru ditinjau dari diri sendiri menunjukkan pencapaian 82,63\% yang berarti sangat baik, sedangkan kinerja guru ditinjau dari Kepala Sekolah menunjukkan pencapaian $80,25 \%$ yang berarti baik dan kinerja guru yang ditinjau dari siswa menunjukkan pencapaian $77,85 \%$ yang berarti baik pula. (b) Kecenderungan kinerja guru ditinjau dari tiap kompetensi hasilnya menunjukkan bahwa hanya kompetensi kepribadian yang berada pada kategori sangat baik $(81,75 \%)$, sedangkan kompetensi pedagogik $(80,37 \%)$, kompetensi sosial $(80,66 \%)$, dan kompetensi profesional $(76,70 \%)$ pada kategori baik.

Tingkat pendidikan mempunyai sumbangan yang berarti terhadap kinerja guru. Hal ini dapat dilihat dari kecenderungan tingkat pendidikan dan kinerja guru yang hasilnya 
menunjukkan bahwa sebanyak $57,1 \%$ dari guru dengan latar belakang pendidikan tinggi (S2) mempunyai kinerja guru yang sangat baik, $42,9 \%$ mempunyai kinerja guru yang baik, dan tidak ada yang memiliki kinerja guru yang cukup baik, sedangkan untuk guru dengan latar belakang pendidikan rendah (DIII/SM), meski mencapai $100 \%$ hanya mempunyai kinerja guru pada kategori baik dan tidak ada yang mempunyai kinerja guru yang sangat baik.

Pengalaman mengajar mempunyai sumbangan yang berarti terhadap kinerja guru. Hal ini dapat dilihat dari kecenderungan pengalaman mengajar dan kinerja guru yang menunjukkan hasil bahwa $60 \%$ dari guru yang memiliki pengalaman mengajar tinggi (lebih dari 30 tahun) mempunyai kinerja guru pada kategori sangat baik, $40 \%$ mempunyai kinerja guru yang baik, dan tidak ada yang mempunyai kinerja guru pada kategori cukup baik, sedangkan guru yang mempunyai pengalaman mengajar rendah (kurang dari 10 tahun) hanya mencapai 50\% yang memiliki kinerja guru pada kategori sangat baik dan $50 \%$ sisanya memiliki kinerja guru yang baik.

Jalur sertifikasi mempunyai sumbangan yang berarti terhadap kinerja guru. Hal ini dapat dibuktikan dari kecenderungan jalur sertifikasi dan kinerja guru yang menunjukkan hasil bahwa $54,5 \%$ guru yang lulus sertifikasi melalui uji portofolio memiliki kinerja guru yang sangat baik, 45,5\% memiliki kinerja guru yang baik, dan tidak ada yang memiliki kinerja guru yang cukup baik. Untuk guru yang lulus sertifikasi melalui PLPG, hanya 33,3\% guru yang mempunyai kinerja guru pada kategori sangat baik, mencapai $61,9 \%$ guru yang mempunyai kinerja guru pada kategori baik, dan terdapat $4,8 \%$ guru yang memiliki kinerja guru yang cukup baik.

Terdapat dua faktor yang menjadi hambatan guru bahasa Inggris SMA bersertifikat pendidik pascasertifikasi, yaitu faktor internal dan faktor eksternal guru. Faktor internal guru meliputi beban jam mengajar, tuntutan administrasi yang banyak, adanya tugas tambahan, dan penguasaan IPTEK yang kurang, sedangkan faktor eksternal guru meliputi beberapa permasalahan dari siswa dan prasarana pembelajaran.

\section{DAFTAR PUSTAKA}

Blerkom, M. L. V. (2009). Measurement and statistics for teachers. New York: Routledge.
Depdiknas. (2011). Peraturan Menteri Pendidikan Nasional Nomor 11, Tahun 2011, tentang Sertifikasi dalam Jabatan.

Depdiknas. (2007). Peraturan Menteri Pendidikan Nasional Nomor 16, Tahun 2007, tentang Standar Kualifikasi dan Kompetensi Guru.

Depdiknas. (2007). Peraturan Menteri Pendidikan Nasional Nomor 16, Tahun 2007, tentang Standar Kualifikasi dan Kompetensi Guru.

Depdiknas. (2005). Peraturan Pemerintah Republik Indonesia Nomor 19, Tahun 2005, tentang Standar Nasional Pendidikan.

Hornby, A. S. (1987). Oxford advance learner's dictionary of current English, revised and update. London: Oxford University Press.

Mulyasa, E.. (2007). Standar kompetensi dan sertifikasi guru. Bandung: Remana Rosda Karya.

Republik Indonesia. (2003). Undang-Undang Republik Indonesia Nomor 20, Tahun 2003, tentang Sistem Pendidikan Nasional.

Republik Indonesia. (2005). Undang-Undang Republik Indonesia Nomor 14, Tahun 2005, tentang Guru dan Dosen.

Reynolds, C. R., Livingson R. B., \& Willson V. (2010). Measurement and assessment in education. New Jersey: Pearson Education.

Samani, Muchlas. (2006). Mengenal sertifikasi di Indonesia. Surabaya: Penerbit SIC.

Sardjunani, Nina. (2012). Arah Pembangunan Kependudukan dan Keluarga Berencana dalam RKP 2012 dan Rancangan RKP 2013. Diakses tanggal $20 \quad$ Februari 2012 dari http://www.bkkbn.go.id/materi/Docume nts/Materi\%20Rakernas\%202012/Papar an\%20bappenas\%20rakernas\%20BKK BN\%202012\%20\%28RKP\%202013\%2 
9\%20revisi\%20DI\%20\%5BCompatibili ty\%20Mode\%5D.pdf

Triyono, Moch Bruri., Kartowagiran, Badrun., \& Retnawati, Heri. (2012). Evaluasi kinerja guru profesional. Diakses tanggal 31 Juli 2012, dari http://staff.uny.ac.id/sites/default/files/br uritriyono/Artike1\%20Lit\%20Stranas09-Bruri.pdf
Waluyo, G. Budi. (2011). Tunjangan sertifikasi dan kinerja guru. Diakses tanggal 3 Januari $2010 \quad$ dari http://www.ybhk.or.id/sites/default/ files/Tunjangan $\% 20$ Sertifikasi\%20dan \%20Kinerja\%20Guru\%20$\% 20 \mathrm{G} \% 20 \mathrm{Budi} \% 20 \mathrm{Waluyo.pdf}$

Yamin, Martinis \& Maisah. (2010). Standarisasi kinerja guru. Jakarta: Gaung Persada Press. 